\title{
PENERAPAN PEMBELAJARAN PROBLEM POSING MELALUI TUTORIAL ONLINE DAN TATAP MUKA UNTUK MENINGKATKAN HASIL BELAJAR DITINJAU DARI TINGKAT AKTIVITAS BELAJAR MAHASISWA PADA PEMAHAMAN MATERI FISIKA DASAR
}

\author{
Sulistyaning Kartikawati \\ Program Studi Pendidikan Teknik Elektro, FPTK, IKIP PGRI MADIUN \\ E-mail : listyosulistyaningkartikawati@yahoo.co.id
}

\begin{abstract}
Abstrak
Penelitian ini merupakan penelitian eksperimen dan dilaksanakan pada semester gasal tahun akademik 2011/2012 dengan populasi sebanyak 83 mahasiswa dengan sampel sebanyak 54 mahasiswa terdiri dari klas $3 A$ sebanyak 26 mahasiswa dan klas $3 B$ sebanyak 28 mahasiswa. Dari hasil analis data diperoleh: 1) Terdapat perbedaan pengaruh pembelajaran problem osing melalui tutorial online dan tatap muka terhadap prestasi belajar, karena $F$ hitung lebih besar dari $F$ tabel, 2) Terdapat perbedaan pengaruh antara mahasiswa yang memiliki aktivitas tinggi dan yang memiliki aktivitas rendah terhadap prestasi belajar, karena $F$ hitung lebih besar dari $F$ tabel, 3) Tidak terdapat interaksi antara pembelajaran problem posing melalui tutorial online dan tatap muka dengan aktivitas tinggi dan aktivitas rendah terhadap prestasi belajar, karena $F$ hitung lebih kecil dari F tabel.
\end{abstract}

Kata Kunci: Problem Posing, Online, Tatap Muka, Aktivitas, Prestasi Belajar

\section{PENDAHULUAN}

Tujuan yang dicanangkan Program Studi Teknik Infomatika STT Dharma Iswara Madiun adalah: Mencetak sumber daya manusia yang terampil di bidang Informatika dan dapat mengaplikasikan Teknologi Informasi pada bidang - bidang lain, sesuai dengan tujuan di atas mahasiswa program studi Teknik Informatika tidak hanya terampil di bidang Informatika saja akan tetapi mahasiswa sebagai calon Sarjana Teknik Informatika harus mampu menguasai ilmu-ilmu lain seperti ilmu Fisika, ilmu Komputasi dan ilmu Matematika yang tercantum sebagai mata kuliah Kurikulum Nasional yang wajib diprogram oleh mahasiswa teknik. Selain itu mengapa mahasiswa Teknik Informatika harus menguasai konsep-konsep fisika secara baik, hal ini dikarenakan konsepkonsep fisika sangat mendasari semua bidang ilmu termasuk bidang Informatika, misalnya: Rangkaian logika, Rangkaian Listrik, Komputasi, Listrik magnet dan masih banyak konsep-konsep fisika yang diperlukan di bidang Informatika.
Fisika adalah Ilmu tentang gejala dan perilaku alam sepanjang dapat diamati manusia. Ilmu fisika perlu diberikan pada mahasiswa di Perguruan Tinggi dengan mempertimbangkan sekurang-kurangnya tiga alasan, yaitu: 1) Ilmu Fisika dipandang sebagai kumpulan pengetahuan yang dapat digunakan untuk membantu penelitian bidang-bidang profesi, 2) Ilmu Fisika dipandang sebagai suatu disiplin kerja yang dapat menghasilkan sejumlah kemahiran generik, 3) Ilmu Fisika ditujukan bagi mereka yang menyenangi kegiatan menggali informasi baru yang dapat ditambahkan pada ilmu fisika yang sudah ada (Brotosiswoyo, 2000 : 1).

Mata kuliah Fisika Dasar merupakan mata kuliah wajib tempuh, yang terdiri dari Fisika Dasar I dan Fisika Dasar II dengan bobot SKS masing-masing 3 SKS. Mata kuliah Fisika Dasar I dan II memiliki cakupan materi yang cukup luas sehingga bobot yang hanya 3 SKS untuk masing-masing cukup menyulitkan pencapaian ketuntasan materi sekaligus ketuntasan belajar. Hal ini terlihat dari hasil nilai ujian akhir semester Mata Kuliah Fisika 
JEMS (Jurnal Edukasi Matematika dan Sains)

Tersedia online di: http://e-journal.ikippgrimadiun.ac.id/index.php/JEMS

Volume 4, Nomor 1, Maret 2016, hal 26 - 35

Dasar I pada semester genap tahun akademik 2010/2011 mahasiswa program studi Teknik Informatika STT Dharma Iswara Madiun yang ditunjukkan pada tabel prosentase nilai ujian akhir semester sebagai berikut: Nilai A sebesar $0 \%$, nilai $\mathrm{AB}$ sebesar $0 \%$, nilai $\mathrm{B}$ sebesar $10 \%$, nilai $\mathrm{BC}$ sebesar $15 \%$, nilai $\mathrm{C}$ sebesar $50 \%$, nilai D sebesar $20 \%$ dan nilai E sebesar 5\%

Nilai $\mathrm{C}$ cukup tinggi prosentasenya, hal ini jauh dari target standar kelulusan yang ditetapkan oleh program studi yaitu untuk mata kuliah Dasar umum lulus minimal nilai BC. Dari hasil pengamatan untuk mata kuliah Fisika Dasar I rerata mahasiswa masih kesulitan dalam menyerap dan memahami materi Fisika Dasar I. Mahasiswa kurang dapat memahami konsep dasar fisika yang sederhana.Akibatnya dosen perlu ekstra waktu dalam menggali pengetahuan mahasiswa. Mahasiswa kesulitan dalam memahami sesuatu yang abstrak, mahasiswa masih sangat pasif dalam menggali informasi tambahan yang mendukung materi yang telah disampaikan dosen. Selama ini, dominasi dosen masih terlalu besar dalam proses pembelajaran. Model perkuliahan bersifat klasikal ditambah dengan tugas yang diberikan dosen kepada mahasiswa masih menyisakan kesulitan pada mahasiswa dalam menyerap informasi yang diberikan oleh dosen. Pembelajaran lebih menekankan pada mahasiswa untuk meniru. Ada kecenderungan dosen memberikan tugas mandiri kurang bervariasi, memberi dalam bentuk soal-soal bukan pemecahan masalah. Oleh karena itu diperlukan suatu model pembelajaran yang dapat meningkatkan daya serap, pemecahan konsep, kemampuan abstrak mahasiswa serta dapat meningkatkan aktivitas belajar mahasiswa dalam pemecahan suatu masalah fisika.

Dalam pembelajaran Fisika, penyelesaian soal-soal berperan penting dalam meningkatkan pemahaman mahasiswa sehingga tidak hanya terbatas pada mekanisme penggunaan rumusrumus semata. Penyelesaian soal -soal dalam fisika penting untuk menuntun mahasiswa memahami pengetahuan yang abstrak. Semakin memahami pengetahuan yang abstrak serta keterkaitannya, mahasiswa akan mampu berpikir dan menyelesaikan soal-soal fisika dalam waktu yang relatif singkat. Oleh karena itu, dosen harus memberi keleluasaan berpikir bagi mahasiswa untuk menyelesaikan soal soal.

Untuk menunjang pemahaman materi dengan strategi pemberian tugas pengajuan soal juga diperlukan model pembelajaran. Selain menggunakan strategi pembelajaran, upaya melatih mahasiswa memiliki pemahaman materi adalah menggunakan berbagai media atau alat bantu pembelajaran diantaranya melalui program komputer, Heinich dkk (dalam Pribadi, 2004) mengemukakan sejumlah kelebihan penggunaan media komputer dalam pembelajaran. Pembelajaran dengan komputer dapat menciptakan iklim belajar yang lebih efektif bagi mahasiswa yang lambat belajar dan memacu keefektifan belajar bagi mahasiswa yang cepat belajar. Pembelajaran dengan komputer termasuk didalamnya pembelajaran online memungkinkan mahasiswa dapat melakukan kegiatan belajar secara mandiri tanpa terikat oleh waktu dan tempat karena dapat diakses melalui internet, dapat menumbuhkan sikap positif mahasiswa terhadap materi dan proses belajar, dapat mengajarkan konsep-konsep aturan, prinsip, langkah-langkah proses dan kalkulasi yang kompleks, dapat menjelaskan konsep tersebut secara sederhana dengan penggabungan visual dan audio yang dianimasikan.

\section{METODE PENELITIAN}

Penelitian ini mengambil lokasi di Program Studi Teknik Informatika Fakultas Teknik STT Dharma Iswara Madiun. Penelitian ini dilaksanakan pada semester gasal Tahun Akademik 2011/2012. Dalam penelitian ini yang menjadi populasi adalah seluruh mahasiswa Teknik Informatika STT Dharma Iswara Madiun yang memprogram mata kuliah Fisika Dasar II sejumlah 82 mahasiswa terdiri dari 3 klas yaitu klas A (26 mahasiswa), klas B (28 mahasiswa) dan klas C (28 mahasiswa). Dalam penelitian ini yang menjadi sampel adalah mahasiswa Program Studi Teknik Informatika yang memprogram matakuliah Fisika Dasar II yaitu klas A sejumlah 26 mahasiswa dan klas B sejumlah 28 mahasiswa. Dalam penelitian ini baik kelas kontrol maupun eksperimen dikenai perlakukan, namun perlakukan yang diberikan beda. Kelompok A 


\section{JEMS (Jurnal Edukasi Matematika dan Sains)}

Tersedia online di: http://e-journal.ikippgrimadiun.ac.id/index.php/JEMS

Volume 4, Nomor 1, Maret 2016, hal 26 - 35

diberi perlakukan pembelajaran pengajuan soal (problem posing) melalui tutorial online, sedangkan kelompok B diberi perlakuan pembelajaran pengajuan soal (problem posing) melalui tatap muka. Setelah itu hasil keduanya dibandingkan, mana yang lebih baik dari kedua pembelajaran tersebut.

Analisa data dilakukan untuk mengetahui dan menguji kebenaran hipotesis yang diajukan. Dalam penelitian ini cara untuk menganalisis data digunakan statistik inferial. Data dianalisis dengan Anava dua jalan dengan desain faktorial (2 $\mathrm{x}$ 2), namun sebelumnya dilakukan uji prasyarat yaitu uji normalitas dan uji homogenitas.

Uji Hipotesis yang digunakan adalah analisis variansi (ANAVA) dua jalan $2 \times 2$ frekuensi sel tidak sama. Jika pengujian prasyarat uji anava terpenuhi yaitu sampel berdistribusi normal dan homogen maka pengujian hipotesis dilakukan dengan pengujian anava pada taraf signifikan 5\%. Dan apabila terjadi hubungan yang memiliki pengaruh sama dari faktor basis media pembelajaran pengajuan soal (Problem Posing) melalui tutorial online dan tatap muka terhadap prestasi mahasiswa, maka digunakan metode Scheffe untuk uji lanjut Anava. Uji lanjut Anava merupakan tindak lanjut dari analisis Anava apabila hasil dari analisis variasi menunjukkan bahwa hipotesis nol ditolak. Tujuan dari uji lanjut Anava ini adalah untuk melakukan pengecekan terhadap rerata setiap pasangan kolom, baris, dan pasangan sel sehingga diketahui bagian mana sajakan terdapat rerata yang berbeda. Sebagai tindak lanjut dari analisis variansi dua jalan adalah menggunakan uji Scheffe untuk uji rerata. Tujuan dari uji Scheffe adalah untuk melakukan pelacakan terhadap perbedaan rerata setiap pasangan kolom, baris dan setiap pasangan sel.

Adapun desain faktorial penelitian tertuang dalam table 1 sebagai berikut :

\begin{tabular}{ccc} 
Tabel 1 : Desain & Faktorial Penelitian \\
\hline \multirow{2}{*}{$\begin{array}{c}\text { Aktivitas } \\
\text { belajar } \\
\text { mahasiswa }\end{array}$} & \multicolumn{2}{c}{ Pembelajaran Problem Posing } \\
\cline { 2 - 3 } Ontine (A1) & Tatap Muka (A2) \\
\hline Tinggi (B1) & A1B1 & A2B1 \\
Rendah(B2) & A1B2 & A2B2
\end{tabular}

\section{Hasil Penelitian dan Pembahasan}

\section{Data Prestasi Belajar mahasiswa Sebelum Pembelajaran}

Dalam penelitian ini data prestasi belajar mahasiswa sebelum pembelajaran yang

\begin{tabular}{ccccc} 
Tabel 2 Deskripsi Data & \multicolumn{5}{c}{ Prestasi Sebelum Pembelajaran } \\
\hline Kelompok & $\begin{array}{c}\text { Jumlah } \\
\text { Mhs }\end{array}$ & $\begin{array}{c}\text { Nilai } \\
\text { Maks }\end{array}$ & $\begin{array}{c}\text { Nilai } \\
\text { Min }\end{array}$ & Rata-rata \\
\hline Eksp I & 26 & 79 & 50 & 62,27 \\
Eksp II & 28 & 70 & 39 & 57,00
\end{tabular}

Dari Tabel 2 tentang deskripsi data prestasi mahasiswa sebelum pelaksanaan penelitian terlihat bahwa nilai maksimal untuk kelas 3A sebesar 79 dan nilai minimal sebesar 50 dengan nilai rata-rata kelas sebesar 62,27. Sedangkan untuk kelas 3B diperoleh nilai maksimal sebesar 76 dan nilai minimal sebesar 39 dengan nilai rata-rata kelas sebesar 57,00. Dari data tersebut di atas terlihat bahwa kelas 3A lebih baik dibandingkan dengan kelas 3B, digunakan yaitu data nilai rata-rata mata kuliah fisika dasar I yang dilaksanakan sebelum penelitian dilaksanakan. Deskripsi data prestasi belajar tersebut dapat ditunjukkan pada Tabel 2 . hal ini disebabkan karena mahasiswa dari kelas 3A lebih serius dan lebih memperhatikan dalam proses pembelajaran dibandingkan mahasiswa kelas 3B.

\section{Data Aktivitas Mahasiswa Sebelum Pembelajaran}

Data tentang aktivitas belajar mahasiswa diperoleh dari nilai aktivitas, selanjutnya dikelompokkan dalam 2 kategori berdasarkan 
JEMS (Jurnal Edukasi Matematika dan Sains)

Tersedia online di: http://e-journal.ikippgrimadiun.ac.id/index.php/JEMS

Volume 4, Nomor 1, Maret 2016, hal 26 - 35

rentang nilai yaitu aktivitas tinggi dan aktivitas

dan aktivitas rendah sebagai berikut:

rendah. Adapun tabel jumlah aktivitas tinggi

Tabel 3 Jumlah mahasiswa Aktivitas Tinggi dan Aktivitas Rendah

\begin{tabular}{lcclll}
\multirow{2}{*}{ Aktivitas } & \multicolumn{2}{c}{ Kelas 3A } & \multicolumn{2}{c}{ Kelas 3B } \\
\cline { 2 - 3 } \cline { 5 - 6 } & Frekuensi & Presentase & FreKuensi & Presentase \\
\hline Tinggi & 17 & 65,38 & 15 & 53,57 \\
Rendah & 9 & 34,61 & 13 & 46,42 \\
\hline Jumlah & 26 & 100 & 28 & 100 \\
\hline
\end{tabular}

Dari Tabel 3 tentang jumlah siswa aktivitas tinggi dan aktivitas rendah menunjukkan bahwa kelas 3A yang mempunyai aktivitas tinggi sebanyak 17 mahasiswa dengan prosentase sebesar $65,38 \%$ dan untuk aktivitas rendah sebanyak 9 mahasiswa dengan prosentase sebesar $34.61 \%$. Sedangkan untuk kelas 3B yang mempunyai aktivitas tinggi sebanyak 15 mahasiswa dengan prosentase sebesar 53,57 \% dan untuk aktivitas rendah sebanyak 13 mahasiswa dengan prosentase sebesar 46,42 \%. Dari data tersebut di atas menunjukkan bahwa kelas 3A lebih aktif dibandingkan kelas 3B, hal ini disebabkan

Tabel 4. Nilai Hasil Belajar

\begin{tabular}{lcccc}
\hline Kelompok & $\begin{array}{l}\text { Jumlah } \\
\text { Siswa }\end{array}$ & $\begin{array}{l}\text { Nilai } \\
\text { Maksimal }\end{array}$ & $\begin{array}{l}\text { Nilai } \\
\text { Minimal }\end{array}$ & $\begin{array}{l}\text { Rata- } \\
\text { rata }\end{array}$ \\
\hline Eksperimen & 26 & 92 & 51 & 66.85 \\
\hline Kontrol & 28 & 75 & 49 & 63.53 \\
\hline
\end{tabular}

Dari Tabel 4 tentang data nilai hasil belajar untuk kelas dengan model pembelajaran kooperatif dengan pengajuan soal (problem possing) melalui tutorial online diperoleh melalui tes yang dilakukan dengan menggunakan soal tes prestasi belajar ranah kognitif. Nilai hasil tes belajar fisika didapatkan nilai terendah 51 dan tertinggi 92, sedangkan nilai rata-rata diperoleh 66,85 . Data nilai hasil belajar untuk kelas dengan pembelajaran pengajuan soal (problem posing) melalui modul tatap muka diperoleh nilai terendah 49 dan nilai tertinggi 75 , sedangkan nilai rata-rata diperoleh 63,53. Dari data tersebut di atas menunjukkan bahwa setelah dilakukan penerapan model pembelajaran nilai prestasi belajar dan nilai rata-rata kelas dari kelas 3A maupun kelas 3B mengalami peningkatan.

\section{Data Aktivitas Belajar Setelah Pembelajaran}

karena kelas 3A kebanyakan belum bekerja sehingga disaat belajar di kelas tidak merasa malas untuk belajar.

\section{Data Prestasi Belajar Mahasiswa Setelah Pembelajaran}

Data prestasi belajar mahasiswa setelah pembelajaran dalam penelitian ini adalah data tes hasil belajar ranah kognitif setelah proses pembelajaran selesai. Sebaran data nilai hasil tes belajar ranah kognitif dari masing-masing kelompok disajikan dalam Tabel 4.

\section{Deskripsi data setelah pembelajaran dengan mahasiswa yang memiliki aktivitas tinggi.}

Dari 26 mahasiswa sebagai responden didapatkan nilai terendah 55, nilai tertinggi 89 dan rata-ratanya adalah 71,88. Adapun distribusi frekuensi hasil belajar mahasiswa yang memiliki aktivitas tinggi. mahasiswa kelas 3A dengan aktivitas tinggi sebanyak 14 mahasiswa, sedangkan untuk aktivitas rendah sebanyak 12 mahasiswa. Deskripsi data setelah pembelajaran aktivitas mahasiswa rendah. Dari 28 mahasiswa sebagai responden didapatkan nilai terendah 55 , nilai tertinggi 85 , dan rataratanya adalah 71,18. Adapun distribusi frekuensi hasil belajar mahasiswa yang memiliki aktivitas rendah. Mahasiswa kelas 3B dengan aktivitas tinggi sebanyak 17 mahasiswa, sedangkan untuk aktivitas rendah sebanyak 11 mahasiswa. 


\section{JEMS (Jurnal Edukasi Matematika dan Sains)}

Tersedia online di: http://e-journal.ikippgrimadiun.ac.id/index.php/JEMS

Volume 4, Nomor 1, Maret 2016, hal 26 - 35

\section{Pengujian Prasyarat Analisis}

\section{Uji Normalitas Sebelum Pembelajaran}

Dalam penelitian ini uji normalitas menggunakan uji normalitas Liliefors dengan tingkat signifikan 5\%. Uji normalitas ini dimaksudkan untuk mengetahui apakah sampel sebelum pembelajaran dilaksanakan berdistribusi normal. Nilai yang digunakan untuk perhitungan ini diambil dari nilai ujian akhir semester sebelum proses penelitian dilaksanakan pada kelas 3A (eksperimen I) dan pada kelas 3B (eksperimen II). Ringkasan analisisnya sebagai berikut:

\begin{tabular}{lccc}
\multicolumn{2}{c}{ Tabel 5 Uji Normalitas Sebelum Proses Pembelajaran } \\
\hline $\begin{array}{c}\text { Kelompok } \\
\text { kelas }\end{array}$ & Nilai uji & $\begin{array}{c}\text { Nilai } \\
\text { tabel }\end{array}$ & Keterangan \\
\hline Eksperimen I & 0,129 & 0,174 & Normal \\
\hline Eksperimen II & 0,148 & 0,174 & Normal \\
\hline
\end{tabular}

Kelompok eksperimen I menunjukkan $\mathrm{L}_{\mathrm{obs}}=0,129$ dan kelompok eksperimen II menunjukkan $\mathrm{L}_{\mathrm{obs}}=0,148$ dengan taraf signifikansi $\alpha=5 \%$. Daerah kritik untuk uji ini adalah $\mathrm{DK}=\left\{\mathrm{L} \mid \mathrm{L}>\mathrm{L}_{0,05 ; 30}=0,174\right\}$. Hal ini berarti $\mathrm{H}_{0}$ yaitu sampel berasal dari populasi yang berdistribusi normal diterima, maka sampel untuk kelompok eksperimen I dan eksperimen II berasal dari populasi yang berdistribusi normal. Pembahasan uji normalitas untuk kelompok eksperimen I dan eksperimen II.

\section{Uji Homogenitas Sebelum Pembelajaran}

Dalam penelitian ini uji homogenitas dilakukan terhadap nilai ujian akhir semester pada kelas 3A (eksperimen I) dan pada kelas 3B

untuk mengetahui apakah sampel berasal dari populasi yang homogen atau tidak. Uji homogenitas menggunakan uji $\mathrm{F}$ dengan taraf signifikan 5\%, dengan hasil yang diperoleh adalah $F_{\text {obs }}=1,385$. Daerah kritik untuk uji ini adalah $F_{0.05 ;(30-1),(30-1)}=F_{0.05 ; 29,29}=1,950$. Ini berarti $\mathrm{H}_{0}$ diterima sehingga dapat disimpulkan data sampel random kedua kelompok homogen.

\section{Uji Normalitas Prestasi Belajar Setelah Pembelajaran}

Dalam penelitian ini digunakan uji Liliefors dengan tingkat signifikan 5\%. Uji normalitas ini menggunakan nilai hasil tes yang dilakukan setelah proses penelitian selesai. Ringkasan analisisnya sebagai berikut: (eksperimen II). Uji homogenitas digunakan

\begin{tabular}{lccc}
\multicolumn{4}{l}{ Tabel 6. Uji Normalitas Setelah Proses Pembelajaran } \\
\hline $\begin{array}{l}\text { Kelompok } \\
\text { kelas }\end{array}$ & Nilai uji & Nilai tabel & Keterangan \\
\hline Eksperimen I & 0,130 & 0,174 & Normal \\
\hline Eksperimen II & 0,170 & 0,174 & Normal
\end{tabular}

Kelompok eksperimen I menunjukkan $\mathrm{L}_{\text {obs }}=0,130$ dan kelompok eksperimen II menunjukkan $\mathrm{L}_{\mathrm{obs}}=0,170$ dengan taraf signifikansi $\alpha=5 \%$. Daerah kritik untuk uji ini adalah $\mathrm{DK}=\left\{\mathrm{L} \mid \mathrm{L}>\mathrm{L}_{0,05 ; 30}=0,174\right\}$. Hal ini berarti $\mathrm{H}_{0}$ yaitu sampel berasal dari populasi yang berdistribusi normal diterima, maka sampel untuk kelompok eksperimen I dan eksperimen II berasal dari populasi yang berdistribusi normal. Pembahasan uji normalitas untuk kelompok eksperimen I dan eksperimen II.

\section{Uji Normalitas Aktivitas Mahasiswa Setelah Pembelajaran}

Uji normalitas aktivitas mahasiswa ini menggunakan uji Liliefors dengan tingkat signifikan 5\%. Ringkasan analisisnya sebagai berikut:

\begin{tabular}{lccc}
\multicolumn{4}{l}{ Tabel 7. Uji Normalitas Aktivitas siswa } \\
\hline $\begin{array}{l}\text { Kelompok } \\
\text { kelas }\end{array}$ & Nilai uji & $\begin{array}{l}\text { Nilai } \\
\text { tabel }\end{array}$ & Keterangan \\
\hline $\begin{array}{l}\text { Aktivitas } \\
\text { tinggi }\end{array}$ & 0,190 & 0,174 & Normal \\
\hline $\begin{array}{l}\text { Aktivitas } \\
\text { rendah }\end{array}$ & 0,250 & 0,167 & Normal \\
\hline
\end{tabular}


Kelompok aktivitas tinggi menunjukkan $\mathrm{L}_{\mathrm{obs}}=0,190$ dengan taraf signifikansi $\alpha=5 \%$. Daerah kritik untuk uji ini adalah $\mathrm{DK}=\{\mathrm{L}|\mathrm{L}\rangle$ $\left.\mathrm{L}_{0,05 ; 31}=0,174\right\}$. Kelompok aktivitas rendah menunjukkan $\mathrm{L}_{\mathrm{obs}}=0,250$ dengan taraf signifikansi $\alpha=5 \%$. Daerah kritik untuk uji ini adalah $\mathrm{DK}=\left\{\mathrm{L} \mid \mathrm{L}>\mathrm{L}_{0,05 ; 29}=0,167\right\}$. Hal ini berarti $\mathrm{H}_{0}$ yaitu sampel berasal dari populasi yang berdistribusi normal diterima, maka sampel untuk kelompok aktivitas tinggi dan kelompok aktivitas rendah berasal dari populasi yang berdistribusi normal. Pembahasan uji normalitas untuk kelompok aktivitas tinggi dan aktivitas rendah.

\section{Homogenitas Prestasi Belajar Setelah Pembelajaran}

Dalam penelitian ini uji homogenitas dilakukan terhadap tes hasil belajar mahasiswa pada kelas 3A (eksperimen I) dan pada kelas 3B (eksperimen II). Uji homogenitas digunakan untuk mengetahui apakah sampel berasal dari populasi yang homogen atau tidak. Uji homogenitas menggunakan uji $\mathrm{F}$ dengan taraf signifikan 5\%, dengan hasil yang diperoleh adalah $\mathrm{F}_{\mathrm{obs}}=0,330$. Daerah kritik untuk uji ini adalah $F_{0.05 ;(30-1),(30-1)}=F_{0.05 ; 29,29}=1,950$. Ini berarti $\mathrm{H}_{0}$ diterima sehingga dapat disimpulkan sampel kelompok eksperimen I dan kelompok eksperimen II berasal dari populasi yang homogen.

\section{Homogenitas Aktivitas mahasiswa Setelah Pembelajaran}

Uji homogenitas digunakan untuk mengetahui apakah setiap tingkat aktivitas mempunyai variansi yang sama. Uji homogenitas menggunakan uji $\mathrm{F}$ dengan taraf signifikan 5\%, dengan hasil yang diperoleh adalah $\mathrm{F}_{\mathrm{obs}}=1,060$. Daerah kritik untuk uji ini adalah $F_{0.05 ;(29-1),(31-1)}=F_{0.05 ; 28,30}=1,950$. Ini berarti $\mathrm{H}_{0}$ diterima sehingga dapat disimpulkan sampel kelompok aktivitas tinggi dan kelompok aktivitas rendah berasal dari populasi yang homogen.

\section{Hasil Pengujian Hipotesis}

Analisis uji prasyarat yang telah dilakukan menunjukkan bahwa data amatan pada sampel yang diambil berasal dari populasi yang berdistribusi normal serta memiliki variansi yang homogen. Hal ini berarti prasyarat untuk melakukan uji hipotesis dengan teknik uji anava dipenuhi. Rangkuman hasil uji hipotesis pada anava 2 jalan dengan sel tak sama dengan tingkat signifikan $\alpha=0,05$. Hasil analisis variansi dapat disajikan dalam tabel 8 berikut:

\begin{tabular}{lcccccc}
\multicolumn{1}{c}{ Tabel 8. Rangkuman Anava } & Dua Jalan Dengan Sel Tak Sama \\
\hline \multicolumn{1}{c}{ Sumbe } & JK & Dk & RK & $\mathrm{F}_{\text {obs }}$ & F $\alpha$ & Ho \\
\hline Antar & 342,86 & 1 & 306,81 & 6,72 & 0,013 & Ditolak \\
Kolom & 84,33 & 1 & 84,17 & 1,84 & 0,183 & Ditolak \\
Antar Baris & 0,00 & 1 & 0,00 & 0,00 & 0,999 & Diterima \\
Interaksi & 1734,72 & 38 & 1734,72 & - & - & - \\
Dalam & & & & & & \\
\hline Total & 2161,9 & 41 & - & - & - & - \\
\hline
\end{tabular}

Perhitungan berdasarkan pada Tabel 8 . Hasil analisis menggunakan variansi dua jalan dengan menguji hasil tes hasil belajar ranah kognitif yang dilaksanakan setelah pembelajaran selesai didapatkan kriteria pengujian adalah $H$ diterima jika $F_{0}<\mathrm{F} \alpha$. Dan $H$ ditolak jika $F_{o}>\mathrm{F} \alpha$. Hasil uji hipotesis dengan anava dua jalan diperoleh bahwa: 1) $H 1$ ditolak dan $H_{l 1}$ diterima yang berarti bahwa terdapat perbedaan pengaruh pembelajaran pengajuan soal (problem posing) melalui tutorial online dan tatap muka terhadap prestasi belajar mahasiswa, 2) $\mathrm{H}_{\mathrm{o} 2}$ ditolak dan
$\mathrm{H}_{\mathrm{i} 2}$ diterima yang berarti bahwa terdapat perbedaan pengaruh antara mahasiswa yang memiliki aktivitas belajar tinggi dengan mahasiswa yang memiliki aktivitas rendah terhadap prestasi belajar, 3) $\mathrm{H}_{03}$ diterima dan $\mathrm{H}_{\mathrm{i} 3}$ ditolak yang berarti bahwa tidak terdapat interaksi antara pembelajaran pengajuan soal (problem posing) melalui tutorial online dan tatap muka dengan aktivitas belajar tinggi dan aktivitas belajar rendah terhadap prestasi belajar mahasiswa.

Pembelajaran online ternyata memberikan hasil yang lebih baik daripada 


\section{JEMS (Jurnal Edukasi Matematika dan Sains)}

Tersedia online di: http://e-journal.ikippgrimadiun.ac.id/index.php/JEMS

Volume 4, Nomor 1, Maret 2016, hal 26 - 35

pembelajaran tatap muka sebab pembelajaran online lebih menimbulkan minat belajar mahasiswa, hal ini didorong keinginan untuk berkomunikasi dengan internet dan lebih visual karena di dalamnya terdapat animasinya. Sedangkan pada pembelajaran tatap muka pada awalnya mahasiswa belum memiliki semangat belajar baik secara mandiri maupun kelompok. Mereka masih terpancang pada perintah/tugas yang diberikan oleh dosen baik lewat bahan ajar maupun studi kasus, walaupun di dalam bahan ajar juga memberikan soal dan tugas kelompok - Hal ini bisa dimaklumi, karena mahasiswa semester awal belum dapat beradaptasi cara belajar yang efektif dan efesien pada jenjang perguruan tinggi.

\section{Uji Lanjut Anava}

Berdasarkan hasil hipotesis yang dilakukan oleh peneliti, terdapat Ho yang ditolak. Maka diputuskan untuk melakukan analisis lanjut pasca Anava dengan Menggunakan Estimated Marginal Mean. Uji ini digunakan untuk mengetahui signifikasi perbedaan pengaruh serta interaksi antar pembelajaran dengan aktivitas siswa terhadap prestasi. Uji lanjut dilakukan karena terdapat hipotesis yang ditolak sehingga perlu diketahui seberapa besar perbedaannya atau pengaruhnya terhadap variabel lain. Rangkuman hasil analisis lanjut pasca Anava ditunjukkan pada Tabel 9 berikut ini:

Tabel 9. Rangkuman hasil analisis lanjut pasca Anava

\begin{tabular}{ccccc}
\hline Variabel & Mean & StDev & $\begin{array}{c}\text { Nilai } \\
\text { Max }\end{array}$ & $\begin{array}{c}\text { Nilai } \\
\text { Min }\end{array}$ \\
\hline Prestasi A & 68,90 & 5,13 & 80,00 & 51,00 \\
\hline Prestasi B & 63,19 & 8,09 & 75,00 & 56,00 \\
\hline
\end{tabular}

Berdasarkan Tabel 9 menunjukkan adanya perbedaan antara kelas 3A dengan kelas 3B, sehingga dapat disimpulkan: Ada perbedaan pengaruh pembelajaran pengajuan soal (problem posing) melalui tutorial online dan pembelajaran pengajuan soal (problem posing) melalui tatap muka terhadap prestasi belajar mahasiswa. Dilihat dari nilai rataratanya, terdapat perbedaan yang signifikan antara penggunaan pembelajaran pengajuan soal (problem posing) melalui tutorial online dan tatap muka. Kelas yang diberi pembelajaran melalui tutorial online mempunyai rata-rata nilai prestasi 68,90, sedangkan untuk kelas yang diberi pembelajaran melalui tatap muka mempunyai rata-rata nilai prestasi 63,19 . Jadi kelas yang belajar melalui tutorial online berada pada posisi lebih baik dari kelas yang belajar melalui tatap muka, hal ini menunjukkan bahwa pembelajaran dengan menggunakan tutorial online lebih baik dibandingkan dengan menggunakan pembelajaran tatap muka.

\section{Pembahasan Hipotesis}

\section{Hipotesis Pertama}

$\mathrm{H}_{\mathrm{o} 1}$ : Tidak terdapat perbedaan pengaruh antara pembelajaran pengajuan soal (problem posing) melalui tutorial online dan tatap muka terhadap prestasi belajar.
$\mathrm{H}_{\mathrm{i} 1}$ : Terdapat perbedaan pengaruh antara pembelajaran pengajuan soal (problem posing) melalui tutorial online dan tatap muka terhadap prestasi belajar.

Hasil analisis uji hipotesis pada Tabel 12. Rangkuman anava menunjukkan bahwa harga $F_{\text {obs }}=6,72$, sedangkan harga $F_{\text {tabel }}$ pada taraf signifikansi $5 \%$ dengan $\mathrm{dk}=1$ adalah 0,013 ternyata harga $\mathrm{F}_{\text {obs }}$ lebih besar dari pada harga $F_{\text {tabel }}(6,72>0,013)$. Dengan demikian $H_{\square A}$ menyatakan tidak terdapat perbedaan pengaruh pembelajaran pengajuan soal (problem posing) melalui tutorial online dan tatap muka terhadap prestasi belajar fisika, ditolak.

Perbedaan kedua pembelajaran tersebut didukung pula dari keadaan yang terjadi di saat penelitian. Pada saat pembelajaran dengan menggunakan pembelajaran pengajuan soal (problem posing) melalui tutorial online, mahasiswa cenderung aktif dan fokus memperhatikan penjelasan yang diberikan oleh dosen. Mahasiswa lebih aktif dalam mengajukan dan menyelesaikan soal setiap ada tatap muka. Suasana kelas lebih kondusif dalam proses pembelajaran yang terjadi, dimana para mahasiswa benar-benar lebih konsentrasi dan tidak malas dalam mengikuti proses pembelajaran, hal ini menunjukkan 
JEMS (Jurnal Edukasi Matematika dan Sains)

Tersedia online di: http://e-journal.ikippgrimadiun.ac.id/index.php/JEMS

Volume 4, Nomor 1, Maret 2016, hal 26 - 35

mahasiswa bersemangat mengikuti pembelajaran.

Pada pembelajaran menggunakan pembelajaran pengajuan soal (problem posing) melalui tatap muka, kurang efektif untuk meningkatkan prestasi belajar mahasiswa karena mahasiswa masih belum tampak tingkat antusias dalam belajar sehingga dapat mempengaruhi prestasi belajar tidak dapat meningkat secara lebih baik. Suasana kelas pada saat proses pembelajaran cenderung tidak bersemangat serta tidak jarang ada mahasiswa yang membicarakan hal-hal lain diluar cakupan materi dan ada yang mengantuk karena pulang kerja langsung masuk kuliah tanpa istirahat. Pada saat tugas mulai diberikan oleh dosen hanya ada beberapa mahasiswa saja yang aktif mengerjakan ,sedangkan yang lainnya cenderung menunggu jawaban dari teman bahkan tidak terlalu peduli.

\section{Hipotesis Kedua}

$\mathrm{H}_{\mathrm{o} 2}$ : Tidak terdapat perbedaan pengaruh antara mahasiswa yang memiliki aktivitas tinggi dengan mahasiswa yang memiliki aktivitas rendah terhadap prestasi belajar fisika.

$\mathrm{H}_{\mathrm{i} 2}$ :Terdapat perbedaan pengaruh antara mahasiswa yang memiliki aktivitas tinggi dengan mahasiswa yang memiliki aktivitas rendah terhadap prestasi belajar fisika.

Hasil analisis uji hipotesis pada Tabel 12. Rangkuman anava menunjukkan bahwa harga $F_{\text {obs }}=1,84$ sedangkan harga $F_{\text {tabel }}$ pada taraf signifikansi $5 \%$ dengan $\mathrm{dk}=1$ adalah 0,183 ternyata harga $\mathrm{F}_{\text {obs }}$ lebih besar daripada harga $F_{\text {tabel }}(1,84>0,183)$. Dari data tersebut dapat disimpulkan ada perbedaan yang signifikan antara mahasiswa dengan aktivitas tinggi dan mahasiswa dengan aktivitas rendah terhadap prestasi belajar fisika. Dengan demikian $H_{0}$ yang menyatakan tidak terdapat perbedaan pengaruh antara mahasiswa yang memiliki aktivitas tinggi dan mahasiswa yang memiliki aktivitas rendah terhadap prestasi belajar fisika, ditolak.

Dari hasil uji hipotesis tersebut di atas menunjukkan bahwa mahasiswa yang memiliki aktivitas belajar tinggi cenderung mempunyai prestasi yang tinggi dibandingkan dengan mahasiswa yang memiliki aktivitas rendah.

\section{Hipotesis Ketiga}

$\mathrm{H}_{\mathrm{o} 3}$ :Tidak terdapat interaksi antara pembelajaran pengajuan soal (problem posing) melalui tutorial online dan tatap muka terhadap prestasi belajar fisika ditinjau dari aktivitas mahasiswa.

$\mathrm{H}_{\mathrm{i} 3}$ : Terdapat interaksi antara pembelajaran pengajuan soal (problem posing) melalui tutorial online dan tatap muka terhadap prestasi belajar ditinjau dari aktivitas mahasiswa.

Dari hasil analisis uji hipotesis pada Tabel 12 Rangkuman anava menunjukkan bahwa harga $F_{\text {obs }}=0,00$ sedangkan harga $F_{\text {tabel }}$ pada taraf signifikansi 5\% dengan $\mathrm{dk}=1$ adalah 0,999 . Ternyata harga $\mathrm{F}_{\text {obs }}$ lebih kecil dari pada harga $F_{\text {tabel }}(0,00<0,999)$. Dengan demikian berarti $H_{03}$ yang menyatakan tidak ada interaksi antara pembelajaran pengajuan soal (problem posing) melalui tutorial online dan tatap muka terhadap prestasi belajar fisika ditinjau dari aktivitas mahasiswa, diterima.

Hasil analisis data tersebut ternyata tidak mendukung hipotesis yang diajukan di bab II yaitu ada interaksi antara pembelajaran pengajuan soal (problem possing) melalui tutorial online dan tatap muka terhadap hasil belajar fisika ditinjau dari aktivitas mahasiswa. Hal tersebut dikarenakan antara penggunaan model pembelajaran dan aktivitas mahasiswa memberikan pengaruh sendiri-sendiri terhadap hasil belajar fisika. Pada kelas 3A dengan menggunakan pembelajaran pengajuan soal (problem posing) melalui tutorial online mahasiswa yang memiliki aktivitas tinggi memperoleh hasil belajar yang lebih tinggi dari mahasiswa yang memiliki aktivitas rendah.

Pada kelas 3B dengan menggunakan pembelajaran pengajuan soal (problem posing) melalui tatap muka mahasiswa yang memiliki aktivitas tinggi dapat memperoleh hasil belajar yang lebih baik dibandingkan dengan aktivitas rendah. Dari uraian di atas dapat dilihat bahwa tidak ada interaksi antara pembelajaran dan aktivitas siswa ditinjau dari prestasi belajar fisika. Interaksi terjadi manakala suatu variabel bebas memiliki efek-efek berbeda 
terhadap suatu variabel terikat pada berbagai tingkat dari suatu variabel bebas lain. Antara penggunaan model pembelajaran dan aktivitas siswa memberikan pengaruh sendiri-sendiri terhadap hasil belajar fisika sehingga tidak terjadi interaksi.

Hasil penelitian ini memberikan gambaran jelas tentang adanya pengaruh penggunaan model pembelajaran terhadap prestasi mahasiswa yang menempuh matakuliah Fisika Dasar II. Aktivitas belajar mahasiswa dapat dibangkitkan melalui penerapan model pembelajaran yang menarik dipadu dengan sentuhan teknologi informasi.

Penggunaan model pembelajaran kooperatif dengan pengajuan soal (problem posing ) melalui tutorial online dipadu dengan tampilan materi yang lebih interaktif dan inovatif maka akan lebih menimbulkan semangat dan minat belajar mahasiswa. Model pembelajaran kooperatif dengan pengajuan soal (problem possing) melalui modul tatap muka yang hanya menghadirkan ceramah tanpa sentuhan kreativitas dosen menimbulkan kejenuhan belajar, sehingga perlu dihadirkan suatu model pembelajaran yang lebih menarik bagi mahasiswa yaitu pembelajaran tutorial online disertai dengan materi yang bersifat dinamis melalui sentuhan animasi atau flas 8 yang cukup bervariasi tampilannya.

Selain model pembelajaran yang harus dikembangkan, pengajar/dosen harus memperhatikan aktivitas belajar mahasiswa dengan memberikan kuesioner tentang aktivitas belajar.

\section{KESIMPULAN DAN SARAN}

Terdapat perbedaan pengaruh pembelajaran problem posing melalui tutorial online dengan tatap muka terhadap prestasi belajar mahasiswa yang menempuh mata kuliah Fisika Dasar II. Terdapat perbedaan pengaruh antra mahasiswa yang memiliki aktivitas belajar tinggi dan aktivitas belajar rendah terhadap prestasi belajar mahasiswa yang menempuh mata kuliah Fisika Dasar II. Tidak terdapat interaksi antara pembelajaran Problem Posing melalui tutorial online dengan tatap muka terhadap aktivitas belajar tinggi dan aktivitas belajar rendah terhadap prestasi belajar mahasiswa yang menempuh mata kuliah Fisika Dasar II.
Upaya pengajar/dosen untuk dapat meningkatkan pemahaman terhadap konsepkonsep fisika sangat diperlukan sebagai salah satu aspek peningkatan prestasi belajar mahasiswa, inovasi pembelajaran yang membantu mahasiswa memudahkan belajar fisika, mengadopsi berbagai model pembelajaran yang relevan dengan karakter mahasiswa dan lain sebagainya. Model pembelajaran kooperatif dengan pengajuan soal ( problem posing ) melalui tutorial Online telah mampu mendongkrak minat belajar mahasiswa dan berimbas pada peningkatan prestasi belajarnya. Model tersebut lebih digemari mahasiswa karena menampilkan materi yang lebih komunikatif dan dilengkapi dengan proses animasi fenomena fisika sehingga dapat mempermudah pemahaman konsep, karena mahasiswa bisa berulang-ulang untuk mempelajari bab tersebut sampai mereka paham betul.

Namun begitu sentuhan emosional pengajar/dosen belum mampu diperankan oleh komputer sebagai media pembelajaran, sehingga peran dosen sebagai pembimbing, fasilitator proses belajar mengajar masih mendominasi keberhasilan para mahasiswa.

Untuk mendapatkan hasil pemahaman konsep-konsep fisika yang lebih baik, maka diharapkan kepada pengajar/dosen untuk mempersiapkan materi ajar secara online yang interaktif dan inovatif . Disamping itu pengajar/dosen diharapkan melakukan evaluasi terhadap aktivitas belajar mahasiswa secara kontinu agar dapat melihat seberapa besar aktivitas belajar mahasiswa selama mengikuti proses perkuliahan berlangsung. Jika terdapat mahasiswa yang mempunyai aktivitas rendah maka pengajar/dosen diharapkan memberikan tugas-tugas tambahan agar mahasiswa mendapatkan prestasi lebih meningkat.

\section{DAFTAR PUSTAKA}

Brotosiswoyo. (2000). Hakikat Pembelajaran MIPA dan Kiat Pembelajaran Kimia di Perguruan Tinggi. Jakarta : Departemen Pendidikan Nasional

Pribadi, 2004. Ketersediaan dan Pemanfaatan Media dan Teknologi Pembelajaran di Perguruan Tinggi. Jurnal Pendidikan. Volume 5(2): h.145-146 
JEMS (Jurnal Edukasi Matematika dan Sains)

Tersedia online di: http://e-journal.ikippgrimadiun.ac.id/index.php/JEMS

Volume 4, Nomor 1, Maret 2016, hal 26 - 35

2004. Prospek Komputer sebagai Media

Pembelajaran Interaktif dalam Sistem
Pendidikan Jarak Jauh Di Indonesia, Universitas Terbuka. 